Printed in Great Britain

\title{
THE SURVIVAL OF LARVAL FISH IN THE NORTHERN NORTH SEA ACCORDING TO THE QUALITY OF THE SEA WATER
}

\author{
By J. H. Fraser, D.Sc. \\ Marine Laboratory, Aberdeen
}

(Text-fig. I)

For a number of years now the presence of various species of Chaetognatha have been used to indicate sea waters of different qualities resulting from the mixing of water masses of different origins. In the North Sea and English Channel the two most important species are Sagitta elegans in water of mixed oceanic and coastal origin, and S. setosa in the indigenous water.

Russell in his series of papers (1930-47) and Corbin (1948) showed that in the English Channel more young fish were taken in the plankton collections in years when $S$. elegans rather than S. setosa was predominant. Wilson (I95I) showed that certain invertebrate larvae thrived in 'elegans' water better than in 'setosa' water and that this could be associated with some positive beneficial factor in the 'elegans' water rather than something toxic in the 'setosa' water.

In the northern North Sea Fraser (I937) showed that the mixed conditions associated with $S$. elegans gave rise to a richer zooplankton than could be associated with either oceanic or neritic water, and Saville (1959) demonstrated the association of such mixed conditions with the success of haddock broods.

This paper is intended to show that the analysis of this association of successful survival of fish larvae with the mixed conditions typified by the presence of $S$. elegans can be taken further.

\section{THE NORTHERN NORTH SEA}

During the years 1946 to 1950 S. setosa was sufficiently abundant in the northern North Sea for a comparison to be made between the numbers of fish eggs and larvae found in waters where $S$. setosa and $S$. elegans respectively was present. The numbers of fish eggs and fish larvae taken by the Scottish research vessels were divided into four columns according to the Sagitta content of the plankton as shown in Table $\mathrm{I}$. The fish numbers for each month were separately totalled and divided to give the average per haul per month, and the twelve numbers-or less if some months contained no samples-thus obtained were averaged to give the yearly average value given in the table. No very precise comparisons are possible as cruises varied from 
year to year, but such a wide system of averages should smooth out any serious discrepancies due to this factor, and give results which are comparable in a broad sense.

The table illustrates the general lack of young fish (except mackerel) in areas where $S$. setosa was the only chaetognath, and a relative abundance in areas where $S$. elegans was characteristic-see columns IV and VI. The numbers in column IV are, in effect, the demersal fish in general, and when both species of Sagitta are present they are seen to be about half way between those with $S$. elegans or S. setosa only. Mackerel larvae were abundant only in one year of this series - I950-and in 'setosa' water, so that the high figure of I44 in column III is enough to bring the ' $\mathrm{S}$ ' average to 34.4 which is greater than the ' $E$ ' average of $28 \cdot 6$. Removing the weighting by mackerel makes little difference to the years I946-9, but considerably affects I950 so that the average ' $S$ ' number in column IV of 9.4 is much less than the ' $E$ ' number of 28.2. Column V excludes gobies, sandeels, Gadus esmarkii and other nonmarketable species. For clupeoids the figure when both species were present is about the same as when $S$. elegans alone occurred and considerably higher than when $S$. setosa alone was recorded. This suggests, in agreement with Wilson, that no harmful factor exists with $S$. setosa-indeed an occasional 'setosa' sample is found with very high numbers of larvae-but that the mixed condition associated with $S$. elegans has a positive beneficial factor. However, this may be, that it is the survival rather than the spawning of the fish which is affected is shown by the numbers given for planktonic fish eggs which do not indicate that spawning fish show any preference for 'elegans' water, but rather the reverse.

From I95I to $1956 \mathrm{~S}$. setosa was not sufficiently abundant in the northern part of the North Sea for comparisons to continue on the same basis, but the collections when $S$. elegans was absent were sufficiently widespread and numerous for a comparison to be made, using only presence or absence of $S$. elegans. Absence may, of course, be due to either neritic or oceanic conditions or merely to the chance absence in the plankton sample of any specimens. Table 2 contains the results obtained from the years 1946 to 1956 inclusive, and it shows the same tendencies as those shown in Table I, i.e. eggs more numerous where $S$. elegans was absent, but larvae more numerous where it was present.

It is realized that, in so far as the smaller the sample the less would be the chance of finding $S$. elegans and the smaller would be the numbers of fish caught, the simple division into presence or absence of $S$. elegans could result in a spurious correlation between the number of young fish and the Sagitta. However, the same collections treated the same way show the opposite relationship for eggs (column VIII), and this table shows much the same characteristics as Table I where the data are not subject to this criticism. Table 2 does, therefore, appear to have significance. 
TABLE 1. THE RELATIONSHIP BETWEEN SAGITTA ELEGANS AND S. SETOSA AND THE NUMBERS OF YOUNG FISH IN THE PLANKTON COLLECTIONS

I

Year

II

III

IV

Young fish

(less Clupeoids)

(less Clupeoids)

$\overbrace{\mathrm{E}}^{\mathrm{E}+\mathrm{S} \mathrm{S} \quad \mathrm{O}} \overbrace{\mathrm{E} \mathrm{E}+\mathrm{S} \quad \mathrm{S} \quad \mathrm{O}}$

and mackerel)

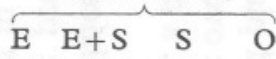

$\begin{array}{llll}2.9 & 3.3 & \text { I }\end{array}$

$\mathrm{E}+\mathrm{S} \quad \mathrm{S} \quad \mathrm{O}$

$\begin{array}{llllll}1946 & 96 & 24 & 19 & 44 & \text { I6 }\end{array}$

$\begin{array}{llllll}1948 & 180 & 51 & 34 & 243 & 27\end{array}$

$\begin{array}{llllrr}1949 & 333 & 94 & 64 & 75 & 26\end{array}$

1950

Average $\begin{array}{llll}16 & 15 & 2.9 & 3.3 \\ 25 & 12 & 5.0 & 19\end{array}$

$\begin{array}{cccc}27 & 22 & 12 & \text { II } \\ 25 & \text { II } & 4.9 & \text { I } 4\end{array}$

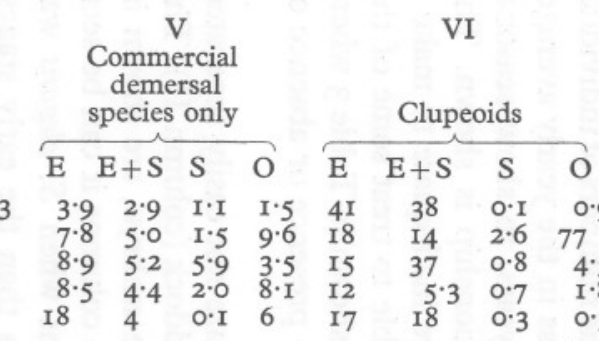

Commercial

see text) to

TABLE 2. THE RELATIONSHIP BETWEEN THE PRESENCE OR ABSENCE OF SAGITTA ELEGANS AND THE NUMBER OF YOUNG

Year $\overbrace{\mathrm{E}}^{\text {No. of hauls }}$

I946 $\quad$ I20 $\quad 63$

947

I 948

1949

1950

I95I

I 952

1954

I955

I956

Average

I20 63

$\begin{array}{ll}195 & 210 \\ 231 & 277\end{array}$

III

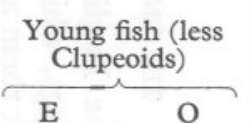

14.9

20.0

23.2

20.5

$49 \cdot 5$

I 4.9

$11 \cdot 8$
$25 \cdot 2$

$25 \cdot 2$

$16 \cdot 0$
$18 \cdot 8$
$20 \cdot 4$

$2 \mathrm{I} \cdot 4$

$\mathrm{E}=S$. elegans present, $\mathrm{O}$

\section{FISH IN THE PLANKTON COLLECTIONS}

\begin{tabular}{|c|c|c|c|c|c|c|c|}
\hline \multicolumn{2}{|c|}{$\begin{array}{l}\text { IV } \\
\text { Young fish (less } \\
\text { Clupeoids and } \\
\text { mackerel) }\end{array}$} & \multicolumn{2}{|c|}{$\begin{array}{c}\text { V } \\
\text { Commercial } \\
\text { demersal } \\
\text { species only }\end{array}$} & \multicolumn{2}{|c|}{$\begin{array}{l}\text { VI } \\
\text { Clupeoids }\end{array}$} & \multicolumn{2}{|c|}{$\begin{array}{l}\text { VII } \\
\text {-commercial } \\
\text { cies only }\end{array}$} \\
\hline $\mathrm{E}$ & $\mathrm{O}$ & E & $\mathrm{O}$ & E & $\mathrm{O}$ & E & $\mathrm{O}$ \\
\hline $\begin{array}{l}14.9 \\
19.9\end{array}$ & $\begin{array}{l}3 \cdot 7 \\
9 \cdot 0\end{array}$ & $\begin{array}{l}2 \cdot 7 \\
6.8\end{array}$ & $\begin{array}{l}I \cdot 6 \\
4 \cdot 2\end{array}$ & $\begin{array}{l}37.8 \\
18.9\end{array}$ & $\begin{array}{r}0.6 \\
16.4\end{array}$ & $\begin{array}{l}12.2 \\
13.1\end{array}$ & $\begin{array}{l}2 \cdot I \\
4 \cdot 8\end{array}$ \\
\hline $23 \cdot I$ & I $2 \cdot I$ & $8 \cdot 4$ & 3.3 & $20 \cdot 7$ & $4 \cdot \mathrm{I}$ & I 4.7 & $\begin{array}{l}4.0 \\
8.8\end{array}$ \\
\hline $20 \cdot I$ & II $\cdot 2$ & $7 \cdot \mathrm{I}$ & 4.8 & 10.8 & I. 7 & 13.0 & $7 \cdot 4$ \\
\hline $48 \cdot I$ & $12 \cdot 3$ & $16 \cdot 2$ & 4.7 & $12 \cdot 6$ & 0.3 & $3 \mathrm{I} \cdot 9$ & $7 \cdot 6$ \\
\hline I2.I & $5 \cdot 6$ & 3.6 & $I \cdot 3$ & 10.4 & 0.3 & 8.5 & 4.3 \\
\hline II $\cdot 8$ & 4.9 & 3.4 & $I \cdot 3$ & $190^{\circ}$ & 0.3 & $8 \cdot 4$ & 3.6 \\
\hline 23.0 & $I \cdot O$ & 13.6 & 0.3 & I5. I & $\mathrm{I} \cdot 2$ & $9 \cdot 4$ & 0.7 \\
\hline $8 \cdot 5$ & $2 \cdot 3$ & 6.8 & $I \cdot I$ & 6.5 & 0.1 & I. 7 & $I \cdot 2$ \\
\hline $\mathrm{I} 4 \cdot \mathrm{I}$ & $9 \cdot 2$ & $6 \cdot 2$ & $4 \cdot 3$ & 4.7 & 0.4 & $7 \cdot 9$ & 4.9 \\
\hline 20.4 & I.7 & 5.4 & 0 & 13.6 & 6.0 & 15.0 & $I \cdot 7$ \\
\hline I9.6 & $6 \cdot 6$ & $7 \cdot 3$ & $2 \cdot 4$ & 15.5 & 2.9 & $12 \cdot 3$ & $4 \cdot 3$ \\
\hline
\end{tabular}

\begin{tabular}{|c|c|c|}
\hline \multicolumn{2}{|c|}{$\begin{array}{l}\text { Planktonic } \\
\text { fish eggs }\end{array}$} & \multirow[b]{2}{*}{$\mathrm{O}$} \\
\hline$E+S$ & S & \\
\hline \multicolumn{3}{|c|}{ No Data } \\
\hline $2 \cdot 9$ & $3 \cdot 1$ & 3.5 \\
\hline I03 & II 7 & 244 \\
\hline 64 & II5 & 34 \\
\hline II9 & II7 & 93 \\
\hline
\end{tabular}


In columns IV to VII of Table 2 none of the possible forty-four pairs of numbers show the presence of more larvae when $S$. elegans was absent although, as would be expected, a small number of the individual samples contributing to these averages do show it.

It will be noted that in comparing the data in Table I with the first 5 years in Table 2 there are apparent discrepancies in the numbers given. This is due to the system of averaging adopted as explained above. For example, E plus $\mathrm{E}+\mathrm{S}$ in Table $\mathrm{I}$ does not equal $\mathrm{E}$ in Table 2 because the numbers of individual samples in each category vary in each month as well as in the yearly average.

If the data are grouped by months instead of years, to show seasonal instead of annual variations, the same type of relationship is shown. The numbers for individual species of fish or fish eggs are inadequate to make a comprehensive specific survey, but it has been possible to treat some of the commoner species separately this way; the results are shown in Table 3 where the numbers are divided, as in Table 2, according to presence or absence of S. elegans.

The early stages of the eggs of cod and haddock are not easily separated and they are grouped together in the table as cod/haddock (column II). The later stages, after development of the pigment in the embryo, are shown in separate columns (columns III and IV). From these columns it can be seen that the early stages were sometimes more abundant when S. elegans was absent, but the later stages, although less numerous than the early stages, were more abundant when it was present. Eggs of whiting and plaice, both fish of a more southerly distribution than cod and haddock were overall more abundant where $S$. elegans was absent, but for long rough dab, a more northerly species in the North Sea, the differences are negligible.

All species of fish larva examined, including whiting and plaice, show a greater average abundance over the eleven year period in the presence of $S$. elegans, and although there are five pairs of monthly figures in the table (one for each of cod, lemon sole and long rough dab and two for 'other flat fish') where the oppo ite is shown - as against sixty-four equal or greater-the difference in each of these instances is less than $0 . \mathrm{I}$.

\section{THE ENGLISH CHANNEL}

Russell in his work in the English Channel, already referred to, did not publish his data on fish eggs, which were not as full as those on the young fish, but he has kindly put them at my disposal. The number of samples per month varied from nil to five and the range in any one month was at times very high (80-7140 in February I93I), high numbers usually being of sprat eggs. Average numbers are perhaps not therefore very reliable but they are given in Table 4 .

These numbers can be added to Russell's pictorial representation of the 
TABLE 3. THE RELATIONSHIP BETWEEN VARIOUS SPECIES OF FISH EGGS AND PLANKTONIC FISH AND THE PRESENCE OR ABSENCE OF SAGITTA ELEGANS IN THE PLANKTON COLLECTIONS

\begin{tabular}{|c|c|c|c|c|c|c|c|c|c|c|c|c|c|c|}
\hline & \multicolumn{2}{|c|}{$\begin{array}{c}\text { I } \\
\text { No. of } \\
\text { samples }\end{array}$} & \multicolumn{2}{|c|}{$\begin{array}{l}\text { II } \\
\text { Cod/haddock } \\
\text { (early stages) }\end{array}$} & \multicolumn{2}{|c|}{$\begin{array}{c}\text { III } \\
\text { Cod } \\
\text { (late stages) }\end{array}$} & \multicolumn{2}{|c|}{$\begin{array}{c}\text { IV } \\
\text { Haddock } \\
\text { (late stages) }\end{array}$} & \multicolumn{2}{|c|}{$\begin{array}{c}\mathrm{V} \\
\text { Whiting }\end{array}$} & \multicolumn{2}{|c|}{$\begin{array}{c}\text { VI } \\
\text { Plaice }\end{array}$} & \multicolumn{2}{|c|}{$\begin{array}{c}\text { VII } \\
\text { L.R.D.* }\end{array}$} \\
\hline & $\mathrm{E}$ & $\mathrm{O}$ & E & $\mathrm{O}$ & $\mathrm{E}$ & O & E & $\mathrm{O}$ & $\mathrm{E}$ & $\mathrm{O}$ & $\mathrm{E}$ & $\mathrm{O}$ & $\mathrm{E}$ & $\mathrm{O}$ \\
\hline $\begin{array}{l}\text { Jan. } \\
\text { Feb. }\end{array}$ & $\begin{array}{l}3 \\
4\end{array}$ & $\begin{array}{l}\mathbf{I} \\
\mathbf{2}\end{array}$ & $\begin{array}{l}2.25 \\
5.83\end{array}$ & $\begin{array}{l}4.50 \\
3.00\end{array}$ & $\begin{array}{l}0.08 \\
0.08\end{array}$ & ० & $\begin{array}{l}0.40 \\
0\end{array}$ & $\begin{array}{l}0.33 \\
0\end{array}$ & $\begin{array}{l}\circ \\
0.23\end{array}$ & ○ & $\begin{array}{l}2 \cdot 37 \\
3 \cdot 73\end{array}$ & $\begin{array}{r}3.80 \\
40.50\end{array}$ & $\begin{array}{l}0 \\
0.38\end{array}$ & $\circ$ \\
\hline Mar. & 6 & 6 & 67.80 & 19.61 & 4.63 & 0.79 & 2.68 & 0.88 & 3.42 & 5.83 & 3.93 & 8.03 & $\mathrm{I} \cdot 30$ & 25.42 \\
\hline Apr. & 7 & 4 & $57 \cdot 4 \mathrm{I}$ & 139.48 & 4 & 0.33 & $10 \cdot 17$ & $7 \cdot 30$ & 5.64 & 19.80 & 8.75 & 0.23 & $36 \cdot 70$ & 31.80 \\
\hline May & 5 & 5 & 7.98 & 34.60 & 0.46 & 0.10 & $2 \cdot 12$ & 0.32 & 3.40 & 4.98 & 0.04 & 0 & 0.22 & 2.06 \\
\hline June & 2 & I & 5.40 & 0.60 & 0.25 & 0 & 0.25 & 0 & 3.00 & 8.80 & 0.23 & $\circ$ & 0 & 0 \\
\hline July & 二 & - & 二 & 二 & - & - & - & - & - & - & - & - & - & - \\
\hline $\begin{array}{l}\text { Aug. } \\
\text { Sept. }\end{array}$ & 二 & 二 & 二 & 二 & $\overline{-}$ & 二 & 二 & 二 & 二 & 二 & 二 & 二 & 二 & 二 \\
\hline Oct. & - & 二 & 二 & 二 & 二 & 二 & 二 & 二 & 二 & 二 & 二 & 二 & 二 & 二 \\
\hline Nov. & - & - & - & - & - & - & - & - & - & - & - & - & - & - \\
\hline Dec. & - & - & - & - & - & - & - & - & - & - & - & - & - & - \\
\hline Total & 6 & 6 & I $46 \cdot 67$ & $201 \cdot 79$ & $9 \cdot 86$ & $I \cdot 12$ & 15.62 & 8.83 & 15.69 & $39 \cdot 4 \mathrm{I}$ & 19.05 & $52 \cdot 56$ & $56 \cdot 6 \mathrm{I}$ & $59 \cdot 28$ \\
\hline Av. & - & - & $24 \cdot 45$ & 33.63 & $I \cdot 64$ & 0.19 & $2 \cdot 60$ & I. 47 & $2 \cdot 6 \mathrm{I}$ & 6.57 & $3 \cdot 17$ & $8 \cdot 76$ & $9 \cdot 44$ & 9.88 \\
\hline
\end{tabular}

\begin{tabular}{|c|c|c|c|c|c|c|c|c|c|c|c|c|c|c|c|c|c|c|c|c|}
\hline & \multicolumn{20}{|c|}{ LARVAE } \\
\hline & \multicolumn{2}{|c|}{$\begin{array}{l}\text { VIII } \\
\text { No. of } \\
\text { samples }\end{array}$} & \multicolumn{2}{|c|}{$\begin{array}{l}\text { IX } \\
\text { Cod }\end{array}$} & \multicolumn{2}{|c|}{$\begin{array}{c}\mathrm{X} \\
\text { Haddock }\end{array}$} & \multicolumn{2}{|c|}{$\begin{array}{c}\text { XI } \\
\text { Whiting }\end{array}$} & \multicolumn{2}{|c|}{$\begin{array}{l}\text { XII } \\
\text { Plaice }\end{array}$} & \multicolumn{2}{|c|}{$\begin{array}{c}\text { XIII } \\
\text { Lemon sole }\end{array}$} & \multicolumn{2}{|c|}{$\begin{array}{c}\text { XIV } \\
\text { L.R.D.* }\end{array}$} & \multicolumn{2}{|c|}{$\begin{array}{c}\text { XV } \\
\text { Gadus } \\
\text { esmarkii }\end{array}$} & \multicolumn{2}{|c|}{$\begin{array}{c}\text { XVI } \\
\text { Other gadoids }\end{array}$} & \multicolumn{2}{|c|}{$\begin{array}{l}\text { XVII } \\
\text { Other } \\
\text { flat fish }\end{array}$} \\
\hline & $\mathrm{E}$ & $\mathrm{O}$ & $\mathrm{E}$ & $\mathrm{O}$ & $\mathrm{E}$ & $\mathrm{O}$ & $\mathrm{E}$ & $\mathrm{O}$ & $\mathrm{E}$ & $\mathrm{O}$ & $\mathrm{E}$ & $\mathrm{O}$ & $\mathrm{E}$ & $\mathrm{O}$ & E & $\mathrm{O}$ & $\mathrm{E}$ & $\mathrm{O}$ & E & $\mathrm{O}$ \\
\hline Jan. & 二 & 二 & 二 & 二 & 二 & 二 & 二 & $=$ & $=$ & $=$ & $=$ & $=$ & - & 二 & - & - & 二 & - & - & - \\
\hline $\begin{array}{l}\text { Feb. } \\
\text { Mar. }\end{array}$ & $\overline{6}$ & $\overline{6}$ & $0 . \overline{39}$ & $0 . \overline{0 I}$ & $0 . \overline{06}$ & $0 . \overline{02}$ & $0 . \overline{05}$ & $0 . \overline{05}$ & 0.05 & $0^{-}$ & $0 . \overline{01}$ & $0^{-}$ & $0 \cdot 13$ & $\overline{0.22}$ & $0 . \overline{89}$ & $\overline{0.01}$ & $15 \cdot \overline{6}$ & $5 \cdot \overline{78}$ & 0 & $\overline{0.01}$ \\
\hline Apr. & 9 & 6 & 0.91 & 0.27 & $\mathrm{I} \cdot 58$ & 0.47 & 0.38 & 0.05 & 0.52 & 0.14 & 0.02 & 0 & $2 \cdot 38$ & 0.17 & 5.05 & 1.03 & II 3 II & 3.97 & 0.33 & 0.24 \\
\hline May & 7 & 7 & $I \cdot 64$ & 0.90 & $5 \cdot 10$ & $1 \cdot 16$ & 3.54 & 2.07 & $0 \cdot 76$ & 0.12 & 0.35 & $0.4 \mathrm{I}$ & 3.27 & 0.54 & 7.00 & $0.9 \mathrm{I}$ & $5 \cdot 84$ & $2 \cdot 26$ & 2.24 & 0.59 \\
\hline June & 9 & 8 & 0.20 & 0.01 & $\mathrm{I} \cdot 70$ & 0.64 & 6.77 & 3.08 & 0.24 & 0.06 & 3.93 & $I \cdot I 5$ & 0.67 & 0.33 & 0.82 & 0.20 & 2.23 & $0.6 \mathrm{I}$ & 4.37 & 0.98 \\
\hline July & 8 & 8 & 0.03 & 0 & 0.31 & 0.23 & $3 \cdot 24$ & $2 \cdot 14$ & 0.57 & 0.01 & 3.49 & 0.65 & 0.39 & 0.06 & 0.09 & 0.03 & 1.00 & 0.45 & $5 \cdot 11$ & 0.97 \\
\hline Aug. & 9 & 8 & 0.01 & 0.06 & 0.01 & 0 & 0.19 & 0.01 & 0.01 & 0.01 & 2.69 & 0.72 & 0.08 & 0.05 & $\circ$ & $\circ$ & 0.14 & 0.01 & 1.68 & 0.44 \\
\hline Sept. & 6 & 5 & 0.02 & 0 & 0 & 0 & 0.06 & 0.06 & 0.02 & 0 & 2.25 & 0.80 & 0.21 & 0 & 0 & 0 & 0.07 & 0.06 & 1.63 & 0.64 \\
\hline Oct. & 9 & 7 & 0.01 & $\circ$ & 0 & 0 & 0.02 & 0 & 0 & 0 & 7.05 & $I \cdot 50$ & 0.15 & 0 & 0 & 0 & 0 & 0 & I.OI & 0.20 \\
\hline Nov. & 8 & 2 & 0 & $\circ$ & $\circ$ & $\circ$ & o & 0 & $\circ$ & $\circ$ & 0.84 & 0 & $\circ$ & $\circ$ & $\circ$ & $\circ$ & $\circ$ & 0 & 0.15 & 0.20 \\
\hline Dec. & 7 & 3 & 0 & $\circ$ & 0 & 0 & $\circ$ & $\circ$ & 0 & 0 & 0.62 & 0 & $\circ$ & $\circ$ & $\circ$ & $\circ$ & $\circ$ & $\circ$ & 0.22 & 0 \\
\hline Total & I0 & Io & 3.21 & $I \cdot 25$ & $9 \cdot 26$ & $2 \cdot 52$ & 14.25 & $7 \cdot 46$ & $2 \cdot 17$ & 0.34 & $21 \cdot 30$ & $5 \cdot 23$ & $7 \cdot 28$ & $x \cdot 37$ & 13.84 & $2 \cdot 18$ & $36 \cdot 75$ & 13.14 & 16.76 & $4 \cdot 27$ \\
\hline Av. & - & - & 0.32 & 0.13 & 0.92 & 0.25 & I. 43 & 0.75 & 0.22 & 0.03 & $2 \cdot 13$ & 0.52 & $0 \cdot 73$ & 0.14 & $I \cdot 38$ & 0.22 & $3 \cdot 68$ & $I \cdot 3 I$ & $I \cdot 68$ & 0.43 \\
\hline
\end{tabular}

$\mathrm{E}=S$. elegans present; $\mathrm{O}=S$. elegans absent.

* L.R.D. = long rough dab (D. platessoides). 
TABLE 4. THE NUMBER OF FISH EGGS (EXCLUDING PILCHARD) TAKEN IN $\frac{1}{2} H$ HAULS WITH THE $2 M$ RING TRAWL IN THE ENGLISH CHANNEL (FROM UNPUBLISHED DATA KINDLY SUPPLIED BY DR F. S. RUSSELL)

\begin{tabular}{|c|c|c|c|c|c|c|c|c|c|c|c|}
\hline & 1930 & I93I & I932 & I933 & 1934 & 1935 & 1936 & I937 & I938 & I939 & $\begin{array}{l}\text { Aver- } \\
\text { age }\end{array}$ \\
\hline & & 680 & - & II 65 & Many & Many & 345 & 71 & I 49 & I 49 & 27 \\
\hline & 73 & 3290 & - & 1320 & Many & $\begin{array}{l}\text { Very } \\
\text { many }\end{array}$ & 1617 & 310 & 1223 & 2081 & I4I8 \\
\hline $\begin{array}{l}\text { ar. } \\
\text { or. }\end{array}$ & $\begin{array}{l}3723 \\
2176\end{array}$ & $\overline{560}$ & - & 2240 & 二 & Many & 540 & $\begin{array}{l}768 \\
630\end{array}$ & $\begin{array}{l}627 \\
348\end{array}$ & $\begin{array}{r}1292 \\
540\end{array}$ & $\begin{array}{r}1532 \\
851\end{array}$ \\
\hline tal & 5972 & 5430 & - & 4725 & - & 一 & 2502 & I 779 & 2347 & 4062 & 4228 \\
\hline $\begin{array}{l}\text { dd average of } \\
\text { issing months }\end{array}$ & 427 & 1523 & - & $85 \mathrm{I}$ & - & - & $85 \mathrm{I}$ & - & - & - & \\
\hline & 6399 & 6062 & - & 5576 & - & - & 3353 & I 779 & 2347 & 4062 & - \\
\hline erag & I562 & 1516 & - & I394 & Many & Many & 838 & 445 & 587 & I016 & 10 \\
\hline
\end{tabular}

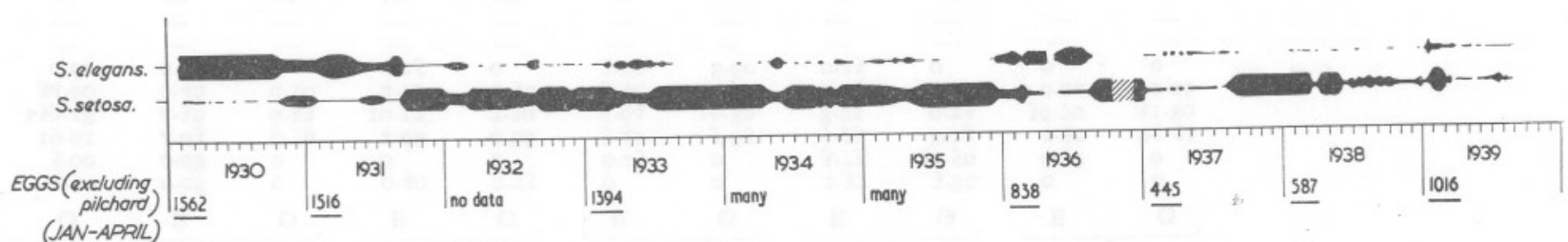

Fig. I. The occurrence of Sagitta elegans and S. setosa off Plymouth, 1930-9 (from Russell), and the average numbers of fish eggs (excluding pilchard) taken in the same years. 
abundance of $S$. elegans and $S$. setosa, taken from his papers, and reproduced here as Fig. I. The main features revealed in this figure are: (I) the high egg numbers of 1930 and I93I associated with S. elegans; (2) the rise in 1939 also associated with a small rise in S. elegans; (3) the increase of S. elegans in 1936 associated with only a poor or average egg content; (4) the high egg figures of 1933 and the 'many' eggs of 1934 and 1935 associated with $S$. setosa; (5) the poorest egg figure (1937) associated with neither and such slight rise as there is to 1938 associated with $S$. setosa. The number of eggs in the English Channel did not therefore follow the same significant pattern in relation to $S$. elegans and $S$. setosa as the larvae. There is, however, a suggestion that the small numbers of young fish after the change in Sagitta contributed to a shortage of eggs in later years, after they had matured.

\section{DISCUSSION}

The data from the English Channel are not directly comparable with the Scottish data presented here. The Channel data are arranged according to years when one species of Sagitta or the other was dominant, and the data from the whole area could thus be compared with the changing water conditions there. They show that in the years when mixed water dominated there were more young fish in the plankton, but the fish eggs were not so directly related. The Scottish data are arranged so that the area investigated is continuously subdivided into sampling localities according to the species of Sagitta present there. The samples were not deliberately selected or collected to test associations of this kind, but were taken incidentally to other investigations. They do strongly suggest, as did Russell's results, the association of better survival of fish larvae with $S$. elegans and mixed water than when $S$. elegans is absent. On the other hand there appears to be no such beneficial association with the production of fish eggs. There is no suggestion, of course, that the presence of $S$. elegans has itself any beneficial effect; indeed as it is a voracious predator the opposite could be assumed.

To explain this better survival we can postulate an increased productivity due to mixing water masses, each with a different limiting factor, and the increased phytoplankton production would lead to a better food supply for the young fish. Huntsman (1920) put forward evidence to show that the 'wrong ' type of water might prevent the development of fish eggs and larvae in the Atlantic near Cape Breton. The effect of different water masses on fish larvae is apparent also under aquarium conditions, and Morris (1956), for example, stated that the more intimate the association of a fish with a particular environment the more difficult it was to rear. A hint, and it is only a hint, that the difference between the survival rate of fish in one water or another is more than merely food supply is given in figures for the eggs of cod and haddock, where a differential survival is indicated before hatching and 
becoming dependent on an outside source of food. This is put forward here without any experimental evidence to support it, but in view of the gradually accumulating evidence of the effects of metabolites on a wide range of marine biological processes it does seem to be a likely possibility.

\section{SUMMARY}

The numbers of fish eggs and planktonic stages of fish taken during a 5-year period by the Scottish research vessels in the northern North Sea have been associated with the presence of Sagitta elegans and S. setosa in the same collections and over an II-year period with the presence or absence of $S$. elegans. The results confirm Russell's findings in the English Channel that fish larvae are more abundant when $S$. elegans is present than when $S$. setosa is present.

The total numbers of fish eggs do not show these differences; spawning does not appear to be any more productive in water associated with S. elegans, rather the reverse, and this is shown to be so for the eggs of those species separately examined. Numbers of the larvae were distinctly greater in the 'mixed' conditions indicated by the presence of $S$. elegans and a more abundant food supply is a possible cause. That the differences may signify a more fundamental effect, however, is suggested by the figures for cod and haddock eggs, which show the earliest stages to be more abundant where $S$. elegans was absent although later stages were more abundant when $S$. elegans was present.

\section{REFERENCES}

Corbin, P. G., I948. On the seasonal abundance of young fish. IX. The year 1947. F. mar. biol. Ass. U.K., Vol. 27, pp. 718-22.

Fraser, J. H., 1937. The distribution of Chaetognatha in Scottish water in 1936, with notes on the Scottish Indicator species. F. Cons. int. Explor. Mer, Vol. I2, pp. 3II-20.

Huntsman, A. G., 1920. Climates of our Atlantic waters. Trans. Amer. Fish. Soc., Vol. 50 (1920-2I), pp. 326-33.

Morris, R. W., 1956. Some aspects of the problem of rearing marine fishes. Bull. Inst océanogr. Monaco, No. I082, pp. I-6I.

RUSSELL, F. S., 1930-47. On the seasonal abundance of young fish, I-VIII. F. mar. biol. Ass. U.K., Vol. 16. pp. 707-22, Vol. 20, pp. 147-79, 595-604; Vol. 21, 679-86; Vol. 22, pp. 493-500; Vol. 23, pp. 381-6; Vol. 24, pp. 265-70; Vol. 26, $605-8$.

SAville, A., 1959. The planktonic stages of the haddock in Scottish waters. Mar. Res. Scot., I959, No. 3, 23 pp.

WILson, D. P., I95I. A biological difference between natural sea waters. F. mar. biol. Ass. U.K., Vol. 30, pp. I-20. 